\title{
EVALUATION OF DIRECT RED 80 DYE ADSORPTION BY CHITOSAN MICROSPHERES
}

\section{AVALIAÇÃo DA ADSORÇÃo DO VERMELHO DIRETO 80 POR MICROESFERAS DE QUITOSẢNA}

\author{
F. S. de O. CRUZ ${ }^{1 *}$, G. A. PUIATTI ${ }^{1}$, T. M. ROCHA ${ }^{1}$, A. F. DE OLIVEIRA ${ }^{1}$, R. P. LOPES ${ }^{1 *}$ \\ ${ }^{1}$ Federal University of Viçosa, Department of Chemistry, Viçosa, Minas Gerais, Brazil
}

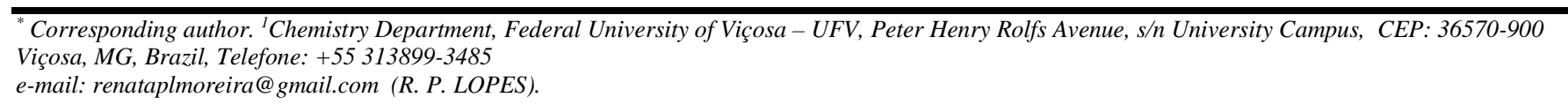

\begin{tabular}{l} 
A R T I C L E I N F O \\
\hline Article history: \\
Received 2018-06-13 \\
Accepted 2018-09-28 \\
Available online 2018-10-31 \\
pa lavras - chave \\
Carvão ativo \\
Adsorção \\
Quitosana \\
ke y words \\
Azo dye \\
Color removal \\
Adsorption
\end{tabular}

\begin{abstract}
A B S T R A C T
The damage caused to the environment by the textile industry creates a demand for simple and inexpensive methods to remove dyes from wastewaters. In this sense, the objective of this work was to evaluate and optimize the adsorption of the Direct Red 80 azo dye by chitosan microspheres. The SEM and FTIR techniques were used to characterize the materials. The results confirmed the occurrence of the adsorption phenomenon by the detection of characteristic bands and changes on the surface of the adsorbent, caused by the fixing of the dye. The response surface methodology in association with a Doehlert matrix was applied to optimize the adsorption process. The obtained response surface presented a saddle point, indicating that the optimal condition is outside of the experimental domain. Isotherms were constructed to describe the adsorption phenomenon. The experimental data presented a better regression adjustment $\left(\mathrm{R}^{2}>0.98\right)$ to the Freundlich nonlinear model. The results demonstrate that the chitosan microspheres presented high color removal efficiency (97\% in 24h) and operational ease in its usage.
\end{abstract}

RES UMO/RES UMEN

Os danos causados ao meio ambiente pela indústria têxtil criam uma demanda por métodos simples e baratos para remover corantes de águas residuárias. Nesse sentido, o objetivo deste trabalho foi avaliar e otimizar a adosorção do corante azo Vermelho Direto 80 por microesferas de quitosana. As técnicas de Microscopia Eletrônica de Varredura e Espectroscopia Vibracional no Infravermelho foram utilizadas para caracterizar os materiais. Os resultados confirmaram a ocorrência do fenômeno de adsorção pela detecção de bandas características e mudanças na superfície do adsorvente, causadas pela fixação do corante. A metodologia de superificie de resposta em associação a uma matriz Doehlert foi utilizada para otimização do processo de adsorção. A superfície de resposta obtida apresentou um ponto de sela, indicando que a condição ótima para os parâmetros se encontra fora do domínio experimental. Isotermas foram construídas para descrever o fenômeno de adsorção. Os dados experimentais apresentaram um melhor ajuste de regressão $\left(R^{2}>0,98\right)$ ao modelo não linear de Freundlich. Os resultados demonstram que as microesferas de quitosana apresentaram elevada remoção de cor $(97 \%$ em $24 \mathrm{~h})$ e facilidade operacional na sua utilização. 


\section{INTRODUCTION}

The textile sector is essential for the economy of a country. However, it is one of the industries that most generate wastewater during its production stages (Holkar et al., 2016; Volmajer et al., 2011). According to Neta et al. (2011), its wastewaters contain dyes applied in the manufacture, which were leached in the process.

The textile wastewaters present low biodegradability and intense color, which are characteristics related to the dyes carried to the affluent of the treatment plants (Kaur et al., 2017; Rodrigues et al., 2010). These dyes cause harmful effects on the environment and human health, such as alteration of the water bodies coloration, which inhibits the photosynthesis, and the generation of carcinogenic and mutagenic by-products (Paz et al., 2017).

The Azo class is the largest group of synthetic industrial dyes present on the market, consequently, it is the most discharged into water bodies (Kallel et al., 2016; Neta et al., 2011). Azo dyes are anionic compounds soluble in aqueous solutions, which exhibit coloration due to presence of certain functional groups in its molecular structure, such as chromophores $(-\mathrm{N}=\mathrm{N}-)$ and the auxochromes $\left(\mathrm{SO}_{3}{ }^{-} ;=\mathrm{O}\right)$ (Verma et al., 2012).

According to the literature, several studies have been focused on the treatment of effluents containing dyes due to their high potential of causing environmental impacts. Physical, chemical and biological processes currently used to treat these effluents exhibit certain inefficiency, as they usually present high cost and/or produce effluents with variable characterisctics, that might contain secondary pollutants and toxic products (Ajmal et al., 2014; Natarajan et al., 2017). According to Kallel et al. (2016), among these processes, adsorption is the simplest and more economical for this purpose.

In this context, there is a demand for low-cost adsorbents generated from plants and animals to be applied on wastewater treatment (Verma et al., 2012). Chitosan (QTS), for example, is a low-cost biopolymer that has shown to be an adsorbent with great potential to remove dyes (Cao et al., 2014).

Chitosan is a product derived from the deacetylation of chitin, the largest component of crustacean exoskeletons (Cao et al., 2014; Rosa et al., 2010). It has been widely applied due to its properties, such as non-toxicity, structural flexibility, adsorptive capacity and the presence of functional groups ($\mathrm{NH}_{2}$ and $-\mathrm{OH}$ ), among others (Cao et al., 2014; Rosa et al., 2010; VAKILI et al., 2015).

In this paper, chitosan microspheres (mQTS) were prepared, characterized and applied on the removal of an azo dye. The Direct Red 80 (DR 80) textile dye was selected for the study because it is commonly used in this industrial sector. Therefore, the objective of this work was to evaluate the sorption capacity of DR 80 by mQTS and to optimize the process using the response surface methodology (RSM) in association with a Doehlert matrix.

\section{MATERIALS AND METHODS}

\subsection{Reagents}

All reagents used in the experiments were obtained from commercial sources, which were: glacial acetic acid (P.A; Manufacturer: ALPHATEC), sodium hydroxide micropearls (P.A; Manufacturer: Impex), ferrous sulphate (P.A; Manufacturer: Dinâmica), nickel nitrate (P.A; Manufacturer: Vetec), ethanol (P.A; Percentage: 99.7\%; Manufacturer: ALPHATEC), sodium borohydride (P.A; Manufacturer: NEON), citric acid (P.A; Percentage: 99.8\%; Manufacturer: NEON), anhydrous dibasic sodium phosphate ACS (P.A; Percentage: 99\%; Manufacturer: VETEC), boric acid (P.A; Percentage: 99.5\%; Manufacturer: VETEC), hydrochloric acid (P.A; Percentage: 37\%; Density: $1.19 \mathrm{~kg} / \mathrm{L}$; Manufacturer: ALPHATEC), sodium nitrate ACS (P.A; Percentage: 99\%; Manufacturer: VETEC). The Direct Red 80 (DR 80) dye and powdered chitosan (QTS) were supplied by the Itabira do Campo Industrial Company and the Environmental Chemistry Laboratory of the Federal University of Viçosa (UFV), respectively.

\subsection{Production of chitosan microspheres}

The chitosan microspheres (mQTS) were obtained by applying the methodology described by Cruz et al. (2015) with some adaptations. For the present study, a single batch of material was produced to be used in all the experiments.

QTS was added in a 5\% (v/v) acetic acid solution to give a final $4 \%(\mathrm{~m} / \mathrm{v})$ QTS solution. Then, the solution was agitated with a vertical stirrer until its homogenization.

Finally, to obtain the mQTS, the produced QTS solution was dripped into an $8 \%(\mathrm{w} v)$ sodium hydroxide solution using a syringe $(\mathrm{v}=5 \mathrm{ml})$, keeping the distance $(\approx 7 \mathrm{~cm})$ between them constant during the procedure. The obtained material was kept at rest for 24 hours. Subsequently, the spheres were washed with distilled water until $\mathrm{pH}$ neutralization.

\subsection{Characterization of materials}

\subsubsection{Diameter of the mQTS}

The diameter of the mQTS was determined using a metal caliper (WESTERN). For this, $50 \mathrm{mQTS}$ were aleatory selected and had its diameter measured. Then, the mean and standard deviation values of the samples were calculated.

\subsubsection{Moisture content of the mQTS}

Fifty mQTS were separated, identified, weighed using an analytical balance (ATX224, Manufacturer: SHIMADZU) and then left to dry under room temperature for 24 hours. After the drying process, the material was reweighed and had its moisture content quantified. Finally, the mean and standard deviation values were calculated.

\subsubsection{Density of the mQTS}

The density of the mQTS was determined by the pycnometry technique using an analytical balance (ATX224, Manufacturer: SHIMADZU). First, the mass of the picnometer was determined. Then, the mass of the picnometer filled with 
distilled water was measured. Subsequently, the mass of a QTS sample $\left(\mathrm{m}_{\mathrm{a}}\right)$ was measured, and then the material was inserted into the picnometer, which had its volume completed with distilled water again. Finally, the mass of this set (picometer + mQTS sample + water) was measured $\left(\mathrm{m}_{\mathrm{c}}\right)$. From this, the density of mQTS could be determined.

\subsubsection{Degree of deacetylation $\left(G_{D}\right)$}

The degree of deacetylation $\left(\mathrm{G}_{\mathrm{D}}\right)$ of the QTS was determined by the Potentiometric Titration method, applying an adaptation of the methodology described by dos Santos et al. (2009). A QTS sample was dissolved in a $0.1 \mathrm{~mol} \mathrm{~L}^{-1} \mathrm{HCl}$ solution in the ratio 1:100 (g QTS / $\mathrm{mL} \mathrm{HCl}$ ). Then, the resultant solution was titrated with a standard $0.1 \mathrm{~mol} / \mathrm{L} \mathrm{NaOH}$ solution under continuous stirring. From the obtained data, the $\mathrm{G}_{\mathrm{D}}$ was determined using the Equation (1).

$$
\mathrm{G}_{\mathrm{D}}=100 \mathrm{xM}_{\mathrm{A}} \mathrm{x} \frac{\Delta \mathrm{VxC}_{\mathrm{NaOH}}}{\Delta \mathrm{VxC}_{\mathrm{NaOH}} \mathrm{x} \Delta \mathrm{M}+\mathrm{m}_{\mathrm{QTS}}} \text {, onde } \Delta \mathrm{M}=\mathrm{M}_{\mathrm{A}}-\mathrm{M}_{\mathrm{D}}
$$

Where: $\mathrm{M}_{D}$ is the deacetylated unit $\left(\mathrm{C}_{6} \mathrm{H}_{11} \mathrm{O}_{4} \mathrm{~N}\right)$ molar mass $\left(161.1558 \mathrm{~g} \mathrm{~mol}^{-1}\right), \mathrm{M}_{\mathrm{A}}$ is the acetylated unit $\left(\mathrm{C}_{8} \mathrm{H}_{13} \mathrm{O}_{5} \mathrm{~N}\right)$ molar mass $\left(203.1925 \mathrm{~g} \mathrm{~mol}^{-1}\right)$ and $\mathrm{C}_{\mathrm{NaOH}}$ is the sodium hydroxide concentration $\left(0.1 \mathrm{~mol} \mathrm{~L}^{-1}\right)$.

\subsubsection{Infrared vibrational spectroscopy (FTIR)}

The materials, mQTS and DR 80, were analysed by Infrared Vibrational Spectroscopy. The infrared spectrum was obtained in the region of $400-4000 \mathrm{~cm}^{-1}$ using an Infrared Spectrophotometer Varian 660-IR with a PikeGladiATR attenuated reflectance accessory.

\subsubsection{Scanning electron microscopy (SEM)}

The materials, mQTSs before (wet) and after being utilized in the DR 80 dye adsorption process, were characterized by Scanning Electron Microscopy.

\subsubsection{Evaluation of the behavior of DR80 as a function of pH}

The behavior of the DR 80 dye in solution was evaluated at different $\mathrm{pH}$ values $(2,4,6,8$ e 10). For this, solutions containing: $15 \mathrm{~mL}$ of dye solution $\left(15 \mathrm{mg} \mathrm{L}^{-1}\right), 5 \mathrm{~mL}$ of universal buffer $\left(0.05 \mathrm{~mol} \mathrm{~L}^{-1} \mathrm{C}_{6} \mathrm{H}_{8} \mathrm{O}_{7} ; 0.05 \mathrm{~mol} \mathrm{~L} \mathrm{~L}^{-1}\right.$ $\mathrm{NaH}_{2} \mathrm{PO}_{4}$ and $\left.0.1 \mathrm{~mol} \mathrm{~L}^{-1} \mathrm{H}_{3} \mathrm{BO}_{3}\right)$ with the $\mathrm{pH}$ adjusted to the desired value and $5 \mathrm{~mL}$ of $\mathrm{NaNO}_{3}\left(0.5 \mathrm{~mol} \mathrm{~L}^{-1}\right)$ were prepared. The spectra were obtained in the range of $200-600 \mathrm{~nm}$.

\subsection{Adsorption tests}

\subsubsection{Adsorption kinetics}

The experiment executed to describe the adsorption kinetics were conducted in a cylindrical reactor containing 250 $\mathrm{mL}$ of a DR 80 solution $\left(15 \mathrm{mg} \mathrm{L}^{-1}\right)$. These experiments were performed without $\mathrm{pH}$ adjustment (natural $\mathrm{pH}$ of the dye solution 6.10), using an mQTS dose of $10 \mathrm{~g} \mathrm{~L}^{-1}$, under orbital agitation (agitator table SL - 180/A, intensity 3) and at room temperature $\left(25 \pm 1^{\circ} \mathrm{C}\right)$. In order to keep track of the adsorption process, aliquots were collected at different time intervals in a $24 \mathrm{~h}$ period, and analysed by UV-Vis Molecular Absorption Spectrophotometry (quartz cuvette, optical path $1 \mathrm{~cm}$ ) monitoring the absorbance at $\lambda=527 \mathrm{~nm}$. The experiments were performed in duplicate.
The remaining concentrations of DR80 in solution were estimated based on an analytical curve in the concentration range of 0-20 $\mathrm{mg} \mathrm{L}^{-1}$. The experimental data were adjusted to a linear model according to the Lambert-Beer Law and the quality of fit was evaluated by the coefficient of determination.

\subsubsection{Optimization of the adsorption process}

The response surface methodology (RSM) in association with a Doehlert matrix was used to evaluate the effects of two variables, the DR 80 initial concentration and the initial $\mathrm{pH}$ of the system, on the color removal. The values adopted in the experiments for these parameters are shown in Table 1. The color removal was determined by UV-Vis Molecular Absorption Spectrophotometry. For this, analytical curves were constructed for each $\mathrm{pH}$ value adopted in the experiments (the absorbance was monitored at the wavelenght of maximum absorption - peak of the spectrum) by varying the dye concentration from 0 to $20 \mathrm{mg} \mathrm{L}^{-1}$. The aliquots were withdrawn after the same time interval taken for the system to reach equilibrium in the adsorption kinetic experiment performed previously (item 2.4.1).

All the experiments were carried out in a $125 \mathrm{~mL}$ cylindrical reactor, containing $5 \mathrm{~mL}$ of universal buffer $(0.05$ mol L $\mathrm{L}^{-1} \quad \mathrm{C}_{6} \mathrm{H}_{8} \mathrm{O}_{7} ; 0.05 \mathrm{~mol} \mathrm{~L}^{-1} \mathrm{NaH}_{2} \mathrm{PO}_{4}$ and $0.1 \mathrm{~mol} \mathrm{~L} \mathrm{~L}^{-1}$ $\mathrm{H}_{3} \mathrm{BO}_{3}$ ) with the $\mathrm{pH}$ adjusted to the desired value, $5 \mathrm{~mL}$ of $\mathrm{NaNO}_{3}(0.5 \mathrm{~mol} \mathrm{~L}-1), 15 \mathrm{~mL}$ of DR 80 solution and $0.25 \mathrm{~g}$ of mQTS.

The obtained spectra were analyzed using the Origin 8.5.9 SR1 software in order to verify the need for baseline correction.

Table 1. The Doehlert matrix design performed to determine the optimal condition for the adsorption of DR 80 by mQTS. The first number is the experimental value and the one inside the parathensis is the coded factor.

\begin{tabular}{ccc} 
Experiment & Initial $\mathrm{pH}$ & Concentration $/ \mathrm{mg} \mathrm{L}^{-1}$ \\
\hline 1 & $2.00(-1)$ & $12.5(0)$ \\
2 & $4.00(-0.5)$ & $20(-0.866)$ \\
3 & $4.00(-0.5)$ & $5(0.866)$ \\
4 & $6.00(0)$ & $12.5(0)$ \\
5 & $8.00(1)$ & $20(-0.866)$ \\
6 & $8.00(1)$ & $5(0.866)$ \\
7 & $10.00(0.5)$ & $12.5(0)$ \\
8 & $6.00(0)$ & $12.5(0)$ \\
9 & $6.00(0)$ & $12.5(0)$ \\
10 & $6.00(0)$ & $12.5(0)$ \\
\hline
\end{tabular}

\subsubsection{Adsorption isotherms}

The equilibrium experiments were performed in a batch cylindrical reactor containing $50 \mathrm{~mL}$ of DR 80 solution, $0.5 \mathrm{~g}$ of mQTS, at $\mathrm{T}=25.2^{\circ} \mathrm{C}$, at $\mathrm{pH}=6,0$ and under constant orbital agitation. The adopted concentrations were 15, 20, 30, 50, 90, 170 and $330 \mathrm{~g} \mathrm{~L}^{-1}$. As described by CHENG et al. (2015), the amount of material adsorbed at equilibrium (Qe) is obtained by the Equation (2):

$$
\mathrm{Q}_{\mathrm{e}}=\frac{\left(\mathrm{C}_{0}-\mathrm{C}_{\mathrm{e}}\right) \mathrm{xV}}{\mathrm{m}}
$$

Where $\mathrm{C}_{0}$ e $\mathrm{C}_{\mathrm{e}}$ are the initial and equilibrium concentrations of the dye in solution respectively; $\mathrm{V}$ is the reaction volume and 
$\mathrm{m}$ is the mass of the adsorbent. The Freundlich's (Equation 3) and the Langmuir's (Equation 4) theoretical models were used to describe the adsorption of DR80 by mQTS.

Freundlich's model: $\mathrm{q}=\mathrm{k}_{\mathrm{F}}\left(\mathrm{C}_{\mathrm{e}}\right)^{\frac{1}{n}}$

Langmuir's model: $\mathrm{q}_{\mathrm{e}}=\frac{\mathrm{q}_{\text {máx }} \mathrm{k}_{\mathrm{L}} \mathrm{C}_{\mathrm{e}}}{1+\mathrm{k}_{\mathrm{L}} \mathrm{C}_{\mathrm{e}}}$

\section{RESULTS AND DISCUSSION}

\subsection{Characterization of Direct Red 80 dye}

UV-Visible absorption spectra as a function of the DR 80 concentration (50 to $5 \mathrm{mg} \mathrm{L}^{-1}$ ) are expressed in the complementary material (Figure $1 \mathrm{~S}$ ). All the solutions under study presented a characteristic absorption band in the visible region $\left(\lambda_{\max }=527 \mathrm{~nm}\right)$ and another two in the UV region $(\lambda=$ $227 \mathrm{~nm}$ and $\lambda=285 \mathrm{~nm}$ ). According to Mahmoodi et al. (2005), the elevated absorption in the visible region corresponds to the chromophore group $(-\mathrm{N}=\mathrm{N}-)$, whereas the ones in the UV refer to benzene and naphthalene rings. This property is also described by $\mathrm{Li}$ et al. (2015), which mention that the absorption in the UV region is a consequence of the presence of benzene-like structures and the one in the visible region is due to an azo bond between two aromatic rings.

The behavior of the DR 80 in solution as a function of the $\mathrm{pH}$ was also evaluated and expressed in the complementary material (Figure 2S). By analysing the curves, it is possible to observe that there was a significant displacement of the absorption peaks correspondent to 285 and $527 \mathrm{~nm}$, whereas there was an increase of the absorbance intensity on the peak located at $227 \mathrm{~nm}$, however, accompanied by a considerable background noise. Therefore, it can be concluded that the wavelength correspondent to the maximum absorbance value is $\mathrm{pH}$ dependent, which justifies the construction of an analitycal curve (Figure 1) for each $\mathrm{pH}$ value adopted in the experiments.

In order to understand this phenomenon occurred in the spectrum, scans were performed in the same regions contemplated in the graphs presented in Figures $1 \mathrm{~S}$ and $2 \mathrm{~S}$ (supplementary material), with DR80 in the used $\mathrm{pH}$ values and the buffer (graphs not expressed in the present work). The results show that the buffer absorbs energy at $\lambda=300 \mathrm{~nm}$ and the absence of other peaks. The dye, however, presents a displacement to the red region only for $\mathrm{pH} 2$ and 4, not showing significant changes for the other $\mathrm{pH}$ values. It can be concluded that the addition of the buffer solution $\left(0.05 \mathrm{~mol} \mathrm{~L}^{-1}\right.$ $\mathrm{C}_{6} \mathrm{H}_{8} \mathrm{O}_{7} ; 0.05 \mathrm{~mol} \mathrm{~L}^{-1} \mathrm{NaH}_{2} \mathrm{PO}_{4}$ and $\left.0.1 \mathrm{~mol} \mathrm{~L}^{-1} \mathrm{H}_{3} \mathrm{BO}_{3}\right)$ and the $\mathrm{pH}$ adjustment cause interactions with the chromophore groups and/or the constituents of the buffer. This results in a bathochromic shift $(\lambda=527$ to $\lambda=541-544 \mathrm{~nm})$ and a hyperchromic effect $(\lambda=212 \mathrm{~nm})$, moreover, the $300 \mathrm{~nm}$ band of the buffer overlaps the DR 80 band.

From these results, analytical curves for the DR 80 were constructed in the studied $\mathrm{pH}$ values, obtained at the maximum absorbance wavelengths $\left(\lambda_{\text {máx }}\right)$. It is possible to visualize that for each analytical curve, a linear relation between the variables is established in agreement with the Lambert-beer Law. The quality of the adjustments was evaluated by the determination and Pearson correlation coefficients, which indicated a positive and linear relationship.
It is possible to discern that the linear model determined for $\mathrm{pH} 6$ presents less sensitivity when compared to the others. Higher sensitivities are observed in more basic conditions. These changes in the sensitivity might be associated with substitutions in the chromogenic reactant molecule caused by its interaction with the $\mathrm{pH}$ and the buffer.

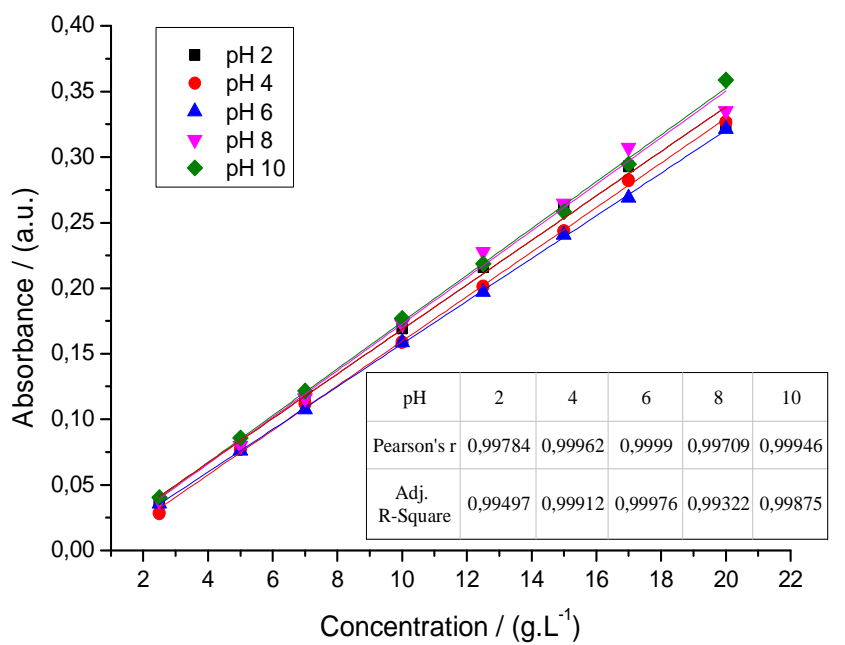

Figure 1. Analytical curves and linear regressions for $\mathrm{pHs}$ $2,4,6,8$ e 10. [DR 80] $=0-20 \mathrm{mg} \mathrm{L}^{-1}, \mathrm{pH}$ adjusted with universal buffer, $\mathrm{T}=25^{\circ} \mathrm{C}$.

\subsection{Characterization of Chitosan microspheres}

The adsorbent used in the experiments was characterized in order to understand its chemical and physical structures and discuss the adsorptive processes involved. A pre-characterization of the mQTS properties is presented in Table 2.

Table 2. Properties of chitosan.

\begin{tabular}{cc}
\hline Parameter & Value \\
Moisture $(\%)$ & $93.400 \pm 0,971$ \\
Mass $(\mathrm{g})$ & $0.0196 \pm 0.0013$ \\
Diameter $(\mathrm{cm})$ & $0.285 \pm 0.063$ \\
Density & $0.971 \pm 0.031$ \\
Deacetylation degree $(\%)$ & $79,11 \pm 1,44$ \\
\hline
\end{tabular}

The produced mQTS (Figure 4) presents a dispersion of diameter (Figure 2, a) inherent of its production process, since the QTS solution is dripped onto the coagulant solution.

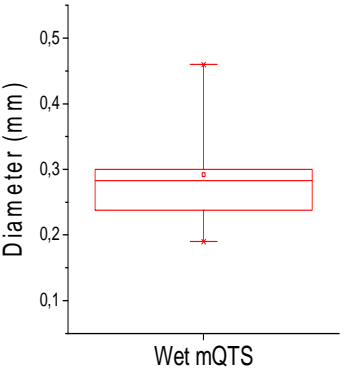

(a)

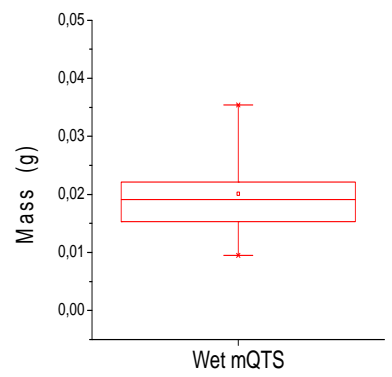

(b)
Figure 2. Box-plot: (a) Diameter and (b) Mass of wet mQTS. Experimental conditions: 50 samples. 
This characteristic is affected by the, amount of material dripped, density of the material and the properties of the solutions. Because of the non-uniformity of the mQTS, its mass values also present a significant dispersion (Figure 2, b) Despite the characteristics of these parameters, the experiments proved to be reproducible and easy to characterize.

The $G_{D}$ was determined by Potentiometric Titration (Figure 3, a). It is possible to observe the presence of three distinct regions, in the first one, the elevation of $\mathrm{pH}$ is caused by the neutralization of free $\mathrm{HCl}$ in solution; the second one, which includes an inflection point, corresponds to the neutralization of the $\mathrm{HCl}$ and the protonated amino groups in the QTS; the third one, is characterized by an increased base excess $(\mathrm{NaOH})$. Thus, it was possible to determine the equivalence point (Figure 3, b), that is, the volume of base needed to neutralize the acid group $\left(\mathrm{NH}_{3}{ }^{+}\right)$and to apply it in Equation 1 to determine the GD, which was equal to $79,11 \pm$ $1,44 \%$.
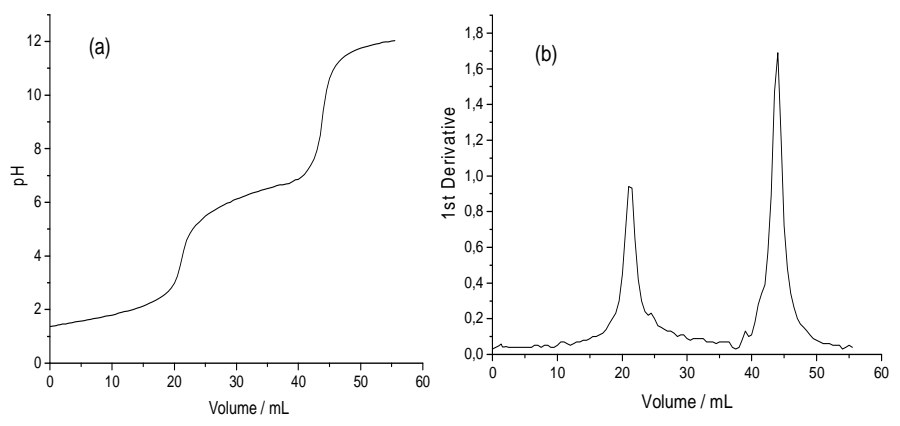

Figure 3. Potentiometric titration: (a) curve of chitosan and (b) 1st derivative of $\mathrm{pH}$.

The morphological studies of the samples were performed by Scanning Electron Microscopy (SEM). The SEM images of mQTSs wet and after the adsorption of the studied dye are presented in Figure 4. The diameter of the mQTS, determined using the ImageJ software, was approximately 1.84 $\mathrm{mm}$, which is inside the dispersion interval presented in Figure 2 (a).

It can be observed that the mQTS have a non-porous surface. An evidence of the adsorption of DR 80 on the surface of the adsorbent was given by SEM (Figure 4, b). This image shows a more regular and grooved surface, which indicates the binding of the dye throughout the entire surface of the mQTS, also shown by the photograph of Figure $3 \mathrm{~S}$ (supplementary material).

Similar results were obtained by Vakili et al. (2015) and Perez et al. (2016). It can also be observed that the mQTS are not totally spherical, presenting a slight tail extension. In agreement with the experiments, this characteristic is directly related to the technique of dripping.

The FTIR technique was used to confirm the occurrence of the adsorption phenomenon, identify the compounds and emphasize the chemical structures before and after the process. In Figure 5 (a) the adsorption band near $3303 \mathrm{~cm}^{-1}$ refers to the vibrations of stretching the bounds of the $-\mathrm{OH}$ and $-\mathrm{NH}$ groups (Vakili et al., 2015). The low-intensity peak at 2885 $\mathrm{cm}^{-1}$ is attributed to the presence of $-\mathrm{CH}$. Regarding the peak appearance at $1637 \mathrm{~cm}^{-1}$, Cao et al. (2014) attributed it to the torsional vibration of the $-\mathrm{NH}_{2}$ and its intensity and area may be consequences of the stretching vibrations of the $\mathrm{C}=\mathrm{O}$ group, bound to the primary and secondary amides, in the region of $1580 \mathrm{~cm}^{-1}$. The peaks of 1421,1382 and $892 \mathrm{~cm}^{-1} \mathrm{~s}$ are resulting from the flexing of the $\mathrm{CH}_{2}, \mathrm{CH}_{3}$ and $\mathrm{C}-\mathrm{H}$ bonds, respectively. In addition, those of 1149 and $1031 \mathrm{~cm}^{-1}$ refer to the stretching vibrations of $\mathrm{C}-\mathrm{OH}$ (Igberase et al., 2014).

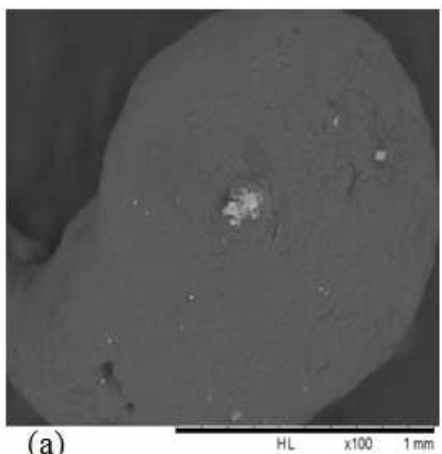

(a)

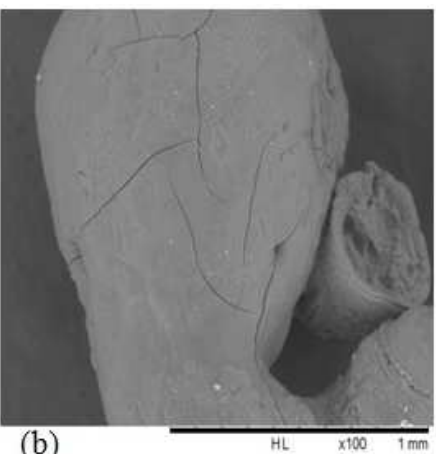

(b)
Figure 4. Images obtained by scanning electron microscopy (SEM) with increase of $x 100$ (a) wet mQTS and (b) mQTS after the process of adsorption of DR 80 .

Regarding Figure 5 (b), the broad and intense peak of $3390 \mathrm{~cm}^{-}$ ${ }^{1}$ refers to the $\mathrm{NH}$ group, indicating the presence of amines and amide. The formation of bands in the region comprised between $1680-1500 \mathrm{~cm}^{-1}$ confirms the existence of these groups. The presence of the stretching band of $\mathrm{C}=\mathrm{O}$ (amide I) is visible, with angular formation of $\mathrm{N}-\mathrm{H}$ (amide band II) and the stretching band of benzene compounds $(\mathrm{C}=\mathrm{C})$. By analyzing the group of sulfones with more than two $\mathrm{S}=\mathrm{O}$ bonds, the spectra exhibit two bands, due to the asymmetrical $\left(1473 \mathrm{~cm}^{-1}\right)$ and symmetrical $\left(1114 \mathrm{~cm}^{-1}\right)$ stretching. For this analysis, we used literary data and approaches described by Barbosa (2007).

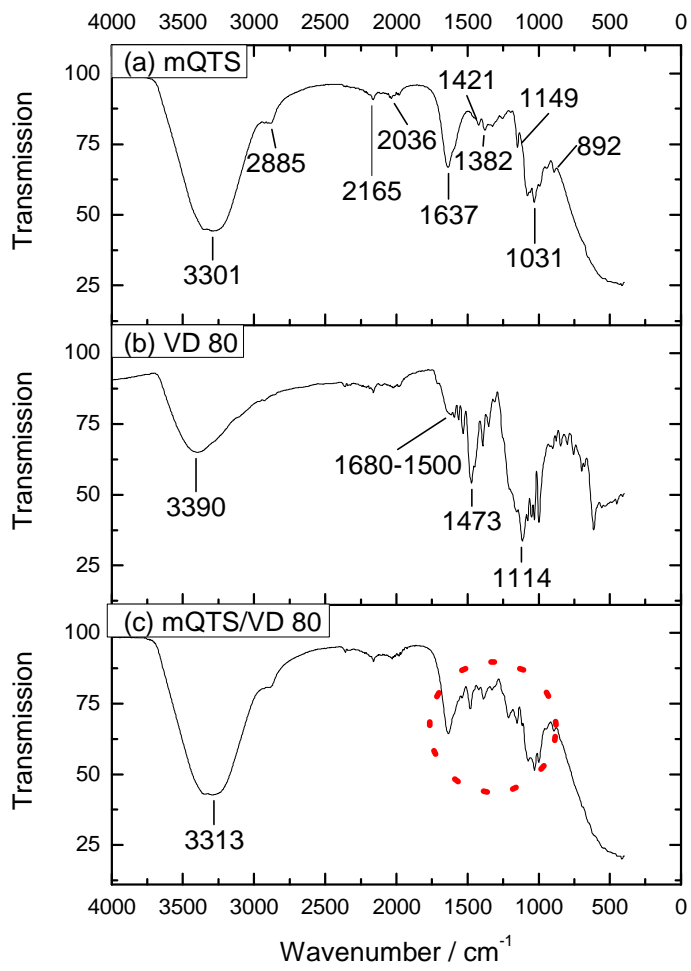


Figure 5. The FTIR spectra of (a) wet mQTS, (b) DR 80, (c) wet $\mathrm{mQTS}$ after the adsorption process of DR 80 .

From the comparative analysis of Figure 5 (c) with (a) and (b), it is possible to understand the spectrum after the adsorptive process. It shows a spectrum modification at the junction of regions 1 and 2 of the spectrum (red circle). This prominent part refers to the functional groups present in both molecules (region 1) and the fingerprint (region 2). These modifications prove the occurance of the adsorption process, in other words, these alterations are justified due to the adsorption mechanism of the system under study. Thus, this phenomenon causes changes in the stretches of the main bonds and/or it simply causes changes of position due to spatial and electronic factors. In addition, it confirms the identity of the new compound, since coupled vibrational bands and vibrations concerning the carbon skeleton of the molecules change (region 2, comparing Figure 5 (a) (b) with respect to (c)).

\subsection{Adsorption kinetics}

The mQTS have been widely applied in studies of color removal (Kimura et al., 1999; Patel et al., 2012; Zhu et al., 2009). This fact is associated to the characteristics of this compound, such as application flexibility (Shukla et al., 2013), ease of characterization and the adsorptive capacity of the $\mathrm{OH}$ and $\mathrm{NH}_{2}$ groups (Igberase et al., 2015).

An approximately $97 \%$ color removal in $24 \mathrm{~h}$ was obtained on the kinetics assay (Figure 6). After reaching this removal value, the system goes into equilibrium.

The adsorption occurs in a casing mode, in other words, around the mQTS. It can be seen in Figures 4 (b) and $3 \mathrm{~S}$ (complementary material), which present the material before and after the process. By analyzing Figure 4, it is clear that the dye adheres to the surface of the mQTS covering it to form a film, which is evidenced by the surface color change shown in Figure 3S (complementary material).

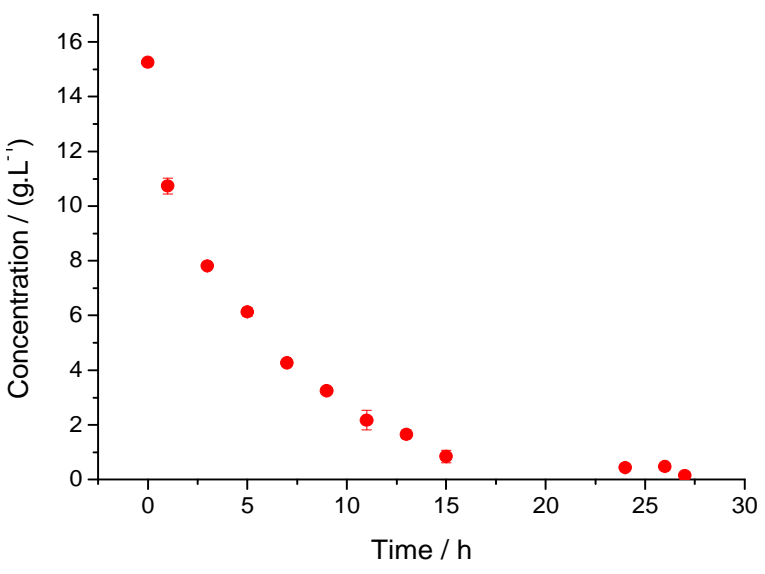

Figure 6. Adsorption kinetics of DR 80 by mQTS.

Experimental conditions: $[\mathrm{mQTS}]=10 \mathrm{~g} \mathrm{~L}^{-1}$, [DR 80] $=15$ ppm, pH without adjustment, $\mathrm{T}=25^{\circ} \mathrm{C}$.

The operational variables of the adsorption process were optimized based on the Doehlert matrix, reducing the number of experiments. The data were treated using the program STATSOFT STATISTICA 7.0.61.0. According to the
Pareto chart (Figure 7), the initial pH and DR 80 concentration, its linear and quadratic relations, and its interactions are statistically significant considering a 95\% confidence limit. The increase in the values of the variables (1) initial $\mathrm{pH}$ and (2) DR 80 initial concentration favors the color removal, as can be visualized in Figure 8.

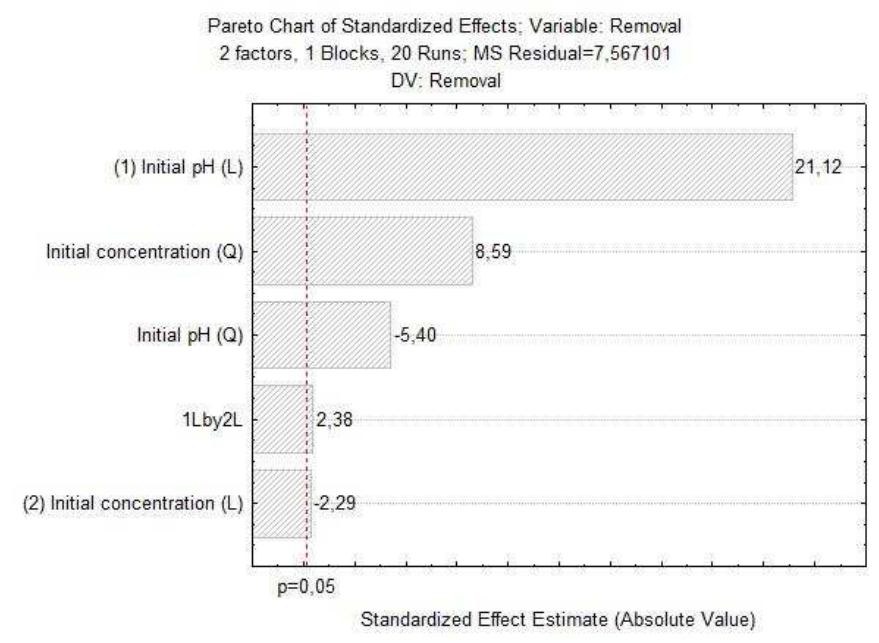

Figure 7. Pareto chart of the pH and initial concentration variables in the DR 80 adsorption.

The results (Figure 8) show that, when working with these factors, the concentration at 3 levels and the $\mathrm{pH}$ at 5 levels, did not contribute to the obtention of an optimal point. However, the constructed experimental design estimated coefficients that presented good adjustments $\left(r^{2}=0.9761\right)$ to the empirical mathematical model employed in the Doehlert matrix within the delimited experimental domain. This methodology uses a quadratic polynomial function (Equation 5) to explore the optimization (Ferreira, 2004).
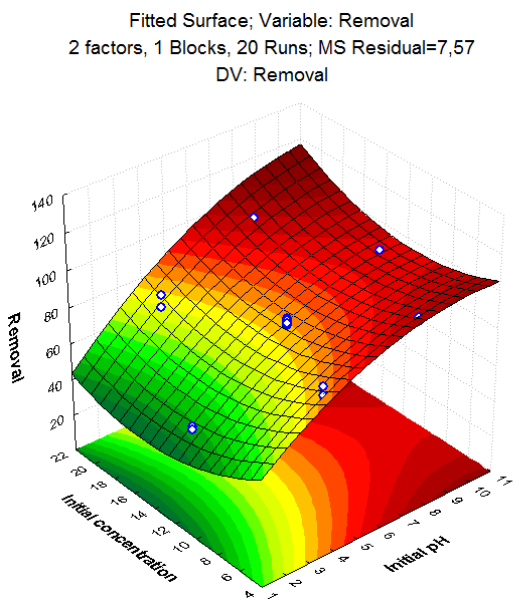

\section{Figure 8. Response surface obtained from the Doehlert Matrix to evaluate the effects of the pH and DR 80 concentration on the color removal.}

From this surface, it was possible to obtain an equation that correlates the color removal with the variables that statistically influence the system. In order to explore information about the critical points, the Lagrange criterion was applied based on the value of the Hessian determinant, in Equation (5), reaching $\operatorname{det}[\mathrm{H}]=-0.46$, characterizing a saddle point (Ferreira, 2004), that is, the meeting of the maximum 
value of one variable with the minimum of the other. For the experimental conditions applied in this methodology, the response surface did not allow to predict data for the optimization of the adsorption of DR 80 by mQTS. However, values of $\mathrm{pH}>6$ provide removals between $80-100 \%$, being excellent results.

$$
Z=69.40+10.83 X-0.57 X^{2}-6.05 Y+0.19 Y^{2}+0.15 X Y
$$

Where, $\mathrm{Z}=$ color removal, $\mathrm{X}=$ initial $\mathrm{pH}$ e $\mathrm{Y}=\mathrm{DR} 80$ initial concentration.

Another important factor in obtaining the response surface was the baseline correction of the spectra, which presented a displacement towards the ordinate axis. Analyzing the color removal phenomenon, Verma et al. (2012) report that mQTS has a long and full chain of free sites for adsorption and neutralization of charges or intermolecular interactions depending on the $\mathrm{pH}$ of the solution. When observing Figure 8, it is evident that independently of the concentration of the studied dye, the increase in $\mathrm{pH}$ favors the color removal phenomenon by the mQTS. According to Li et al. (2005), these alterations on the adsorption process are resultant of the acidbase properties of mQTS (Equations (9) and (10)).

$-\mathrm{NH}_{2}+\mathrm{H}^{+} \leftrightharpoons-\mathrm{NH}_{3}^{+}$

$-\mathrm{NH}_{2}+\mathrm{OH}^{-} \leftrightharpoons-\mathrm{NH}_{2} \mathrm{OH}^{-}$

Through the equations and the knowledge of the DR 80 and mQTS chemical structures, it is possible to infer that the amino group of chitosan will interact by neutralization of charges with the sulphonic group at acidic $\mathrm{pH}$ and by intermolecular interactions at basic $\mathrm{pH}$. Moreover, Verma et al. (2012) mention that the interparticle interaction occurs through $\pi$ electrons of the dye molecule and $-\mathrm{OH}^{-}$group of mQTS.

\subsection{Isotherms}

Adsorption isotherms are fundamental for the understanding of the adsorptive phenomenon between two phases, liquid and solid, in equilibrium. To determine a model that best described the system under study, the Langmuir and Freundlich models were tested. The results were compared using the coefficient of determination $\left(\mathrm{R}^{2}\right)$. The results indicate that the mQTS adsorb DR 80 following a Freundlich's model (Figure 9), since it presented $\mathrm{R}^{2}>0.98$.

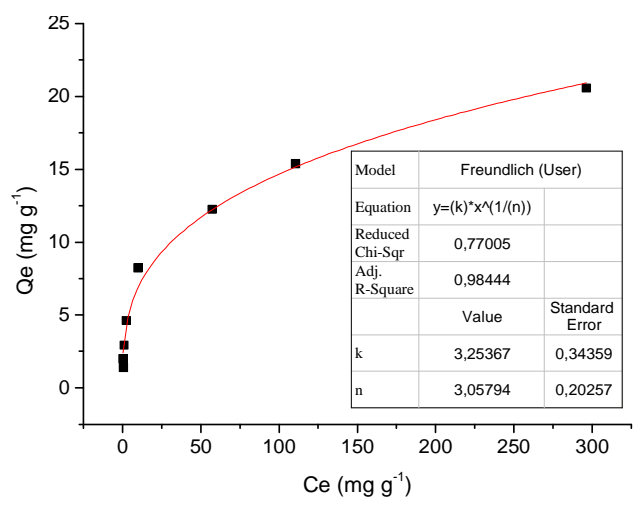

Figure 9. Freundlich's isotherm model adjustment to the experimental data of the DR 80 adsorption by mQTS experiment, Stirring time $=24$ h. Experimental conditions: $[\mathrm{mQTS}]=10 \mathrm{~g} \mathrm{~L}^{-1}$, [DR 80] = $15-500 \mathrm{mg} \mathrm{L}^{-1}$, pH without adjustment, $T=25^{\circ} \mathrm{C}$.

According to Cheng et al. (2015), this mechanism occurs by the adsorption of the studied dye at sites, with distinct energies, present on the heterogeneous surface of the adsorbent. In accordance to the results, the DR80 is retained only on the external specific area of the mQTS.

\section{CONCLUSIONS}

In the present work, chitosan microspheres were tested for the remediation of the Direct Red 80 textile dye. Excellent results were obtained, with a 97\% removal in $24 \mathrm{~h}$. FTIR and SEM analyses showed that the dye adsorbs on the surface of the chitosan microspheres. Assays employing a Resonse Surface Methodology, Doehlert matrix, demonstrated that the $\mathrm{pH}$ of the system strongly influences the adsorption process, altering the adsorption mechanism of the dye molecules by the mQTS (in acid pH - neutralization of charges, while in basic $\mathrm{pH}$ - intermolecular interaction). The experimental data fitted to the Freundlich nonlinear model $\left(\mathrm{R}^{2}=0.98444\right)$. The application of this material for remediation showed to be advantageous due to its high removal capacity, ease of handling, low cost and low environmental impact. Thus, the mQTS presented a potential to be applied in the future to remove color of effluents.

\section{ACKNOWLEDGMENTS}

The authors gratefully acknowledge the CNPq (National Council for Scientific and Technology Development 449909/2014-0 process) for the financial support.

\section{R E F E R E N C E S}

AJMAL, A. et al. Principles and mechanisms of photocatalytic dye degradation on $\mathrm{TiO} 2$ based photocatalysts: a comparative overview. RSC Adv., v. 4, n. 70, p. 37003-37026, 2014.

BARBOSA, L. C. DE A. Espectroscopia no Infravermelho na caracterização de compostos orgânicos. $1^{\mathrm{a}}$ ed. Viçosa: [s.n.].

$\mathrm{CAO}, \mathrm{C}$. et al. In situ preparation of magnetic Fe3O4/chitosan nanoparticles via a novel reduction-precipitation method and their application in adsorption of reactive azo dye. Powder Technology, v. 260, p. 90-97, jul. 2014.

CHENG, Z. et al. Adsorption behavior of direct red 80 and congo red onto activated carbon/surfactant: Process optimization, kinetics and equilibrium. Spectrochimica Acta Part A: Molecular and Biomolecular Spectroscopy, v. 137, p. 1126-1143, fev. 2015.

CRUZ, F. S. DE O.; VIEIRA, F. T.; REIS, A. B. DOS. Obtenção de esferas de quitosana para estudo do comportamento em águas poluídas artificialmente com metais pesados. Anais do XX Congresso Brasileiro de Engenharia Química. Anais...São Paulo: Editora Edgard Blücher, fev. 2015Disponível em: $<$ http://www.proceedings.blucher.com.br/articledetails/17496> 
DOS SANTOS, Z. M. et al. Determination of deacetylation degree of chitosan: a comparison between conductometric titration and $\mathrm{CHN}$ elemental analysis. Carbohydrate Research, v. 344, n. 18, p. 2591-2595, dez. 2009.

FERREIRA, S. Doehlert matrix: a chemometric tool for analytical chemistry-review. Talanta, v. 63, n. 4, p. 1061-1067, jul. 2004.

HOLKAR, C. R. et al. A critical review on textile wastewater treatments: Possible approaches. Journal of Environmental Management, v. 182, p. 351-366, nov. 2016.

IGBERASE, E.; OSIFO, P. Equilibrium, kinetic, thermodynamic and desorption studies of cadmium and lead by polyaniline grafted cross-linked chitosan beads from aqueous solution. Journal of Industrial and Engineering Chemistry, v. 26, p. 340-347, 2015.

IGBERASE, E.; OSIFO, P.; OFOMAJA, A. The adsorption of copper (II) ions by polyaniline graft chitosan beads from aqueous solution: Equilibrium, kinetic and desorption studies. Journal of Environmental Chemical Engineering, v. 2, n. 1, p. 362-369, mar. 2014.

KALLEL, F. et al. Interactive effect of garlic straw on the sorption and desorption of Direct Red 80 from aqueous solution. Process Safety and Environmental Protection, v. 102, p. 30-43, jul. 2016.

KAUR, P.; KUSHWAHA, J. P.; SANGAL, V. K. Evaluation and disposability study of actual textile wastewater treatment by electro-oxidation method using $\mathrm{Ti} / \mathrm{RuO} 2$ anode. Process Safety and Environmental Protection, v. 111, p. 13-22, out. 2017.

KIMURA, I. Y. et al. Efeito do ph e do tempo de contato na adsorção de corantes reativos por microesferas de quitosana. Polímeros, v. 9, n. 3, p. 51-57, 1999.

LI, N.; BAI, R. Copper adsorption on chitosan-cellulose hydrogel beads: behaviors and mechanisms. Separation and Purification Technology, v. 42, n. 3, p. 237-247, abr. 2005.

LI, P. et al. Enhanced decolorization of methyl orange using zero-valent copper nanoparticles under assistance of hydrodynamic cavitation. Ultrasonics Sonochemistry, v. 22 , p. 132-138, jan. 2015.

MAHMOODI, N. M. et al. Decolorization and aromatic ring degradation kinetics of Direct Red 80 by UV oxidation in the presence of hydrogen peroxide utilizing $\mathrm{TiO} 2$ as a photocatalyst. Chemical Engineering Journal, v. 112, n. 1-3, p. 191-196, 2005.

NATARAJAN, S.; BAJAJ, H. C.; TAYADE, R. J. Recent advances based on the synergetic effect of adsorption for removal of dyes from waste water using photocatalytic process. Journal of Environmental Sciences, p. 1-22, mar. 2017.

NETA, J. DE J. DA S. . et al. Use of polyurethane foams for the removal of the Direct Red 80 and Reactive Blue 21 dyes in aqueous medium. Desalination, v. 281, n. 1, p. 55-60, out. 2011.

PATEL, H.; VASHI, R. T. Removal of Congo Red dye from its aqueous solution using natural coagulants. Journal of Saudi Chemical Society, v. 16, n. 2, p. 131-136, 2012.

PAZ, A. et al. Biological treatment of model dyes and textile wastewaters. Chemosphere, v. 181, p. 168-177, ago. 2017.

PEREZ, J. J.; FRANCOIS, N. J. Chitosan-starch beads prepared by ionotropic gelation as potential matrices for controlled release of fertilizers. Carbohydrate Polymers, v. 148, p. 134-142, set. 2016.

RODRIGUES, K. et al. Viabilidade do tratamento de água residuária sintética têxtil em reator aeróbio de leito fixo. Engenharia Sanitaria e Ambiental, v. 15, n. 1, p. 99106, mar. 2010.

ROSA, G. S.; MORAES, M. A.; PINTO, L. A. A. Moisture sorption properties of chitosan. LWT - Food Science and Technology, v. 43, n. 3, p. 415-420, abr. 2010.

SHUKLA, S. K. et al. Chitosan-based nanomaterials: A stateof-the-art review. International Journal of Biological Macromolecules, v. 59, p. 46-58, ago. 2013.

VAKILI, M. et al. Elimination of reactive blue 4 from aqueous solutions using 3-aminopropyl triethoxysilane modified chitosan beads. Carbohydrate Polymers, v. 132, p. 89-96, nov. 2015.

VERMA, A. K.; DASH, R. R.; BHUNIA, P. A review on chemical coagulation/flocculation technologies for removal of colour from textile wastewaters. Journal of Environmental Management, v. 93, n. 1, p. 154-168, jan. 2012.

VOLMAJER VALH, J. et al. Water in the Textile Industry. In: Treatise on Water Science. [s.1.] Elsevier, 2011. p. 685-706.

ZHU, H. et al. Photocatalytic decolorization and degradation of Congo Red on innovative crosslinked chitosan/nano$\mathrm{CdS}$ composite catalyst under visible light irradiation. Journal of Hazardous Materials, v. 169, n. 1-3, p. 933-940, 2009. 